\title{
Sexuality education: Counselling guidelines for the primary care physician
}

\author{
A joint statement of the Adolescent Medicine Committee \\ and the Bioethics Committee
}

Gexuality should be treated as a natural part of life, from birth to adulthood. Ideally, discussions on the subject begin within the family in childhood and continue through adolescence. As the child grows and ventures out to school, socializing and interacting with peers and adults, the practical and broader aspects of sexuality development must be dealt with progressively. This is best done by parents when they have community resources, such as primary care physicians, available to help them.

\section{SEXUALITY DEVELOPMENT IN PREPUBERTAL CHILDREN}

The development of sexuality in children begins in the delivery room as soon as parents hear, "It's a boy!" or "It's a girl!”. Immediately, parents begin the gender acculturation process according to their expectations for girls and boys. Physicians who see families from their inception are in a unique position to give anticipatory guidance and to monitor sexuality development in children. They can play an important role in promoting a positive, natural, open and guilt-free attitude toward the child's body. Primary care physicians can also promote gender equity.

Infancy and early childhood provide many opportunities to discuss the human body, especially around times of bathing and dressing. Children are curious about their bodies and will explore genitals in the same way that they explore fingers, toes or faces. It is good to encourage the use of proper vocabulary for the genital region so that the child and caregiver can use these terms when talking about the child's body.

As the child grows, opportunities will arise to explain rules of respect for one's body, respect for the bodies of others and the issues of privacy and modesty. These discussions about boundaries will also facilitate later discussion to help prevent child sexual abuse. It is important to keep in mind, however, that child sexual abuse is an issue of power and is not preventable simply by educating children.

Primary care physicians can explore sexuality development in an anticipatory manner at the time of routine physical examination. Caregivers often have questions about the appropriateness of sexual play and often want to discuss topics such as masturbation.

Caregivers should have an understanding of healthy, normal sexual behaviour in children and that it is usually motivated by curiosity and interest. Children are often amused by these activities, which are usually limited to looking and touching. Healthy, normal sexual behaviour is generally along the lines of sharing a new discovery with other children or with parents.

Physicians and caregivers should be alerted if the nature of the sexual behaviour is more abusive or exploitative. Such behaviour is usually accompanied by some degree of coercion or bullying, and may involve explicit re-enactment of adult sexual activity. In such cases, children are more often afraid, uncomfortable or ashamed. They may describe the behaviour as 'having sex' or 'sexing'.

This work has been previously published in Paediatr Child Health 1997;2:45-8. 
TABLE 1 Psychosocial development of adolescents

\begin{tabular}{|c|c|c|c|}
\hline Task & Early adolescence & Middle adolescence & Late adolescence \\
\hline \multirow[t]{2}{*}{ Independence } & Less interest in parental activities & Peak of parental conflicts & Reacceptance of parental advice and values \\
\hline & Wide mood swings & & \\
\hline \multirow[t]{2}{*}{ Body image } & $\begin{array}{l}\text { Preoccupation with self and pubertal } \\
\text { changes }\end{array}$ & General acceptance of body & Acceptance of pubertal changes \\
\hline & Uncertainty about appearance & $\begin{array}{l}\text { Concern over making body } \\
\text { more attractive }\end{array}$ & \\
\hline \multirow[t]{3}{*}{ Peers } & Intense relationship with same-sex & Peak of peer involvement & Peer group less important \\
\hline & friend & Conformity with peer values & More time spent in sharing intimate relationships \\
\hline & & $\begin{array}{l}\text { Increased sexual activity and } \\
\text { experimentation }\end{array}$ & \\
\hline \multirow[t]{4}{*}{ Identity } & Increased cognition & Increased scope of feelings & Practical, realistic vocational goals \\
\hline & Increased fantasy world & Increased intellectual ability & Refinement of moral, religious and sexual values \\
\hline & Increased need for privacy & Feelings of omnipotence & Ability to compromise and to set limits \\
\hline & Lack of impulse control & Risk-taking behaviour & \\
\hline
\end{tabular}

TABLE 2

Relationship between adolescent and parental development tasks

\begin{tabular}{|c|c|}
\hline Adolescent task & Parental task \\
\hline $\begin{array}{l}\text { Accept physical } \\
\text { changes of puberty }\end{array}$ & $\begin{array}{l}\text { Accept that the adolescent is no longer } \\
\text { a child and treat as an emerging adult } \\
\text { Recognize that behaviour and mood are } \\
\text { affected by the hormonal changes of } \\
\text { puberty } \\
\text { Allow less physical intimacy and allow for } \\
\text { privacy while maintaining sufficient contact } \\
\text { to demonstrate love and concern }\end{array}$ \\
\hline $\begin{array}{l}\text { Work toward independ- } \\
\text { ence from family or } \\
\text { origin }\end{array}$ & $\begin{array}{l}\text { Determine what behaviours are desired or } \\
\text { undesired (rules) } \\
\text { Determine, communicate and negotiate } \\
\text { limits (boundaries) } \\
\text { Determine, communicate and negotiate } \\
\text { consequences of infractions of rules } \\
\text { (being outside of boundaries) } \\
\text { Adapt to changing needs of adolescent } \\
\text { Teach adolescent how to make decisions } \\
\text { by role modelling }\end{array}$ \\
\hline $\begin{array}{l}\text { Create stable role } \\
\text { identity }\end{array}$ & $\begin{array}{l}\text { Engage in activities enhancing } \\
\text { self-esteem } \\
\text { Recognize parental influence in identity } \\
\text { problems } \\
\text { Maintain longitudinal view of process }\end{array}$ \\
\hline $\begin{array}{l}\text { Develop adult thinking } \\
\text { skills }\end{array}$ & $\begin{array}{l}\text { Differentiate between egocentrism } \\
\text { and selfishness } \\
\text { Recognize personal fable as a transitional } \\
\text { developmental process }\end{array}$ \\
\hline
\end{tabular}

\section{SEXUALITY EDUCATION FOR THE CHILD IN EARLY PUBERTY}

An appropriate time for anticipatory guidance about normally expected body changes is when the physician and parent notice the beginning of the physical growth spurt. The first of these is usually breast budding in girls or testicular growth in boys. The physician may wish to become acquainted with available reading materials for parents and children and have some on hand to loan to families.

In puberty, the focus of control in the patient-physician relationship should begin to shift from parent to child. The early pubertal child should sense that the physician is there for him or her and will maintain appropriate confidentiality. This can be a good time to begin to conduct part of the office visit with the child alone, if the child is comfortable with this. It may be prudent for a parent, guardian or other professional to be on hand for those parts of the visit that include hands-on physical examination.

\section{SEXUALITY EDUCATION FOR THE ADOLESCENT}

The area of sexuality is a major developmental concern during adolescence. Sexuality is an integral part of identity development and is aided by the emergence of appropriate assertiveness, independence and autonomy. Teens may need reassurance about their growth and development. This is particularly true in early-maturing or late-maturing teenagers as well as those with chronic illness.

Adolescents may have worries, questions or misunderstandings about many issues, including masturbation, menstruation, wet dreams, erections, sexual fantasies, orgasms and sexual orientation. Adolescents who have been sexually abused may have difficulty achieving self-identity, especially in the area of sexuality (and sexual function), and may need therapeutic intervention. Teens in residential treatment centres and teens living on the street should not 
be forgotten. The primary care physician may be one of the few information resources available to these adolescents.

\section{General principles for counselling adolescents}

A.Ensure that all education, especially regarding sexuality, is understandable and appropriate to the cognitive and emotional development of the teenager (as shown in the work of Piaget and Erikson; Table 1).

B. Discuss and maintain confidentiality. Explain its limits, ie, with regard to sexual abuse, suicide and homicide. (Physicians should be aware that written documentation may be subpoenaed).

C. Discuss the varieties of normal growth and development. As well, information on the expected developmental tasks is helpful to teenagers and to their parents (Table 2).

D. Remain open to a dialogue around the teenager's current issues of concern and/or areas of misinformation.

E. Explore the teenager's relationship with parents, with peers (both male and female) and with any significant others.

F. Explore the teenager's skill levels, especially in areas such as decision-making. Specifically, go on to discuss the teenager's decisions about sexual activity, using vocabulary that will be understood.

G. Repeat information and discussion a number of times to be effective.

H. Become aware of appropriate community resources and, when appropriate, make referrals. The physician may be 'uncomfortable' around sexuality education in general or specific areas, and still be able to provide counselling effectively.

I. Be available to talk to adolescent patients. Compliance during adolescence, to either medical or behavioural regimens, is fostered by an ongoing, trusting relationship with the physician. Regular contact or ready phone access can be the key to a strong teen-physician relationship.

\section{Specific areas of counselling}

A number of issues arise frequently and deserve special comment. These include permission to say "No" to sexual activity, contraception, sexually transmitted diseases (STDs) and sexual orientation.

Issues for adolescents with special needs, such as chronic illness and developmental disabilities, are explored further in other Canadian Paediatric Society statements (noted in References and Bibliography).

\section{- Saying "No"}

Given that Canadian statistics show that 20\% of 14 -year-olds and $50 \%$ of 16 -year-olds are sexually active and that most teens use no contraception on first intercourse (1), physicians should be prepared to initiate primary prevention through early counselling. Specific discussions around continuing sexual abstinence, delaying sexual activity, or discontinuing high risk or coercive sexual behaviour may be very helpful to the teenager.

\section{- Contraception}

Only a combination of education and service programs actually helps reduce teen pregnancy (2). Contraception should be discussed with both male and female patients who are sexually active or considering it. Whenever possible, both partners should be prepared to take responsibility for preventing pregnancy and STDs.

Gynecological examination is important for sexually active adolescents. Examination should include a Papanicolaou smear, cultures for STDs and bimanual examination for pelvic inflammatory disease. Physicians who do not have the facilities or who do not feel comfortable doing pelvic examinations may use appropriate community clinics and other physicians for referral.

\section{- STDs}

Given the high rate of STDs among adolescents (3) and indications that young adults with HIV contracted the virus during adolescence (4), appropriate education around safer practices should be stressed and explained in detail. Teenagers should also be made aware that STDs may be asymptomatic, especially in females. Sexually active teenagers should be encouraged to have STD testing regularly, as well as when they change partners, and certainly if any symptoms appear. Maintaining regular follow-up visits with sexually active teenagers can help physicians monitor whether this regular testing is being done. Guidelines for the treatment of STDs in children and youth have been published and are available from Health Canada or through local public health offices (See References and Bibliography).

\section{- Sexual orientation}

Adolescents who are involved with sexual experimentation may have concerns about their sexual orientation. Physicians should be prepared to discuss issues of sexual orientation and be aware that teens who are in the process of identifying themselves as homosexual or bisexual can experience a higher incidence of mental health problems, including consideration of or active attempts at suicide.

Physicians can remain open to a teenager's questions about sexual orientation by making no assumptions about this during discussion, especially regarding assumptions about the sex of the teenager's sexual partner. A supportive nonjudgmental approach and assurances of confidentiality are essential. When physicians feel unable to deal with sexual orientation issues in the teens they are seeing, they should refer teens to appropriate community services early. This will help encourage and strengthen family ties, discourage blame and guilt, and provide the teenager and family with needed information (5). 
Homosexual youths may engage in high risk sexual behaviour; therefore, continued reassessment is needed, with anticipatory guidance and encouragement of safer-sex practices.

- Adolescents with developmental disabilities The Canadian Paediatric Society's Adolescent Medicine Committee is developing a statement on issues in teenagers with developmental disabilities, which will be available in the near future.

\section{- Adolescents with chronic illnesses}

Readers are referred to the committee's statement on adolescent issues in youth with chronic illnesses (6).

\section{CONCLUSIONS}

As with other aspects of human development, sexuality should be introduced to the child in a gradual, ageappropriate manner by parents or other caregivers. Physicians can be helpful in providing information and sup-

\section{REFERENCES}

1. King AJ, Beazley RP, Warren WK, et al. Canada Youth and AIDS Study. Kingston: Queen's University (Social Program Evaluation Group), 1988.

2. Stewart DC. Sexuality and the adolescent: Issues for the clinician. Prim Care 1987;14:83-99.

3. Health Canada. 1995 Update: Canadian guidelines for the prevention, diagnosis, management and treatment of sexually transmitted diseases in neonates, children, adolescents and adults. Can Commun Dis Rep 1995;21S4:1-20.

4. Gilmore N. HIV infection in Canada: Prevalence, incidence, outcome and survival. Med North Am 1990;June:896-902.

5. Kaufman M. Answering parents' questions about homosexuality. Can Fam Physician 1991;37:1197-201.

6. Adolescent Medicine Committee, Canadian Paediatric Society. Care of the chronically ill adolescent, AM 94-05. Can J Paediatr 1994;1:124-7.

\section{BIBLIOGRAPHY}

Adolescent Medicine Committee, Canadian Paediatric Society. Office practice guidelines for the care of adolescents, AM 94-04. Can J Paediatr 1994;1:121-3.

Bureau of Communicable Disease Epidemiology. Sexually Transmitted Disease in Canada, 1986. Ottawa: Laboratory Centre for Disease Control, Health Protection Branch, Health and Welfare Canada, 1987.

Docherty J. Growing Up: A Guide for Children and Parents. London: The Royal Society of Medicine, Modus Books, 1986.

From an acorn to an oak tree, Report on Task Force on Adolescent Health. Toronto: College of Family Physicians of Canada, 1993. port to parents and guardians, as well as in reinforcing such education in the doctor's office. Physicians should also be prepared to act as a resource on sexuality in the community. Where there is no continuity of parenting (ie, children in foster and custodial care), physicians can help ensure that these children receive appropriate sexuality education.

The unique opportunity of seeing children and adolescents annually for a complete assessment of health status and during the year for various complaints gives the physician many opportunities to assess and follow development, identifying areas of concern. It is important for physicians and other professionals to learn about all aspects of sexuality development and to be informed about available community resources. There should also be sufficient communication and coordination among parents, educators, community organizations and physicians so that messages conveyed to teenagers are clear, continuous and consistent.

Haka-Ikse K, Mian M. Sexuality in children. Pediatr Rev 1993;4:401-7.

Lipsius SH. Normal sexual development of children: Physician roles in bridging gaps in parent-child communication. Md Med J 1992;41:401-5.

Remafedi GJ, Savin-Williams RC, Troiden RR, et al. Special section on adolescent homosexuality. J Adolesc Health Care 1988;9:93-143.

Wadhera S, Silins J. Teenage pregnancy in Canada, 1975-1987. Fam Plann Perspect 1990;22:27-30.

\section{RESOURCES FOR PARENTS, EDUCATORS AND OTHERS}

Fenwick E, Walker R. How Sex Works. Toronto: MacMillan Publishers, 1995.

Gardner-Loulan J, Lopez B, Quakenbush M. Period. California: Volcano Press, 1991.

Local public health office.

Local Planned Parenthood office.

Madaras L. What's Happening to My Body, A Growing Up Guide for Mothers and Daughters. New York: New Market Press, 1987.

Madaras L. The What's Happening to My Body Book for Boys, A Growing Up Guide for Parents and Sons. New York: New Market Press, 1987.

Magic Lantern Communications, \#38-775 Pacific Road, Oakville, Ontario L6L 6M4. Telephone 1-800-263-1717.

Meredith S. Where Do Babies Come From? London: Usborne Publishing, 1990.

National Film Board of Canada, see local phone directory or call 1-800-267-1710.

Rosenberg E. Growing Up Feeling Good. Toronto: Penguin Books, 1989.

\section{ADOLESCENT MEDICINE COMMITTEE}

Members: Drs Andrew Lynk (director responsible), Sydney, Nova Scotia; Miriam Kaufman (chair and co-author), The Hospital for Sick Children, Toronto, Ontario; Roger Tonkin (co-chair), Sunny Hill Hospital, Vancouver, British Columbia; Lionel Dibden, Edmonton, Alberta; Eudice Goldberg, The Hospital for Sick Children, Toronto, Ontario; Larry Pancer, Markham, Ontario

Consultants: Drs Delores Doherty (co-author), St John's, Newfoundland; Jean-Yves Frappier, Hôpital Ste-Justine, Montreal, Quebec; Diane Sacks (co-author), Toronto, Ontario; Michael Westwood, Dorval, Quebec

Acknowledgements: Dr Suji Lena (former consultant and co-author), Children's Hospital of Eastern Ontario, Ottawa, Ontario

\section{BIOETHICS COMMITTEE}

Members: Drs Keith Goulden (director responsible), Glenrose Rehabilitation Hospital, Edmonton, Alberta; Michael Whitfield (chair), BC's Children's Hospital, Vancouver, British Columbia; Susan Albersheim, BC's Children's Hospital, Vancouver, British Columbia; Jaques Belik, Foothills Hospital, Calgary, Alberta; Graham Chance, St Joseph's Health Centre, London, Ontario; Lawrence Jardine, Janeway Child Health Centre, St John's, Newfoundland

Consultants: Drs Judith Hall, BC's Children's Hospital, Vancouver, British Columbia; Abbyann Lynch, Fitness in Healthcare, Toronto, Ontario; John Watts, Chedoke-McMaster Hospitals, Hamilton, Ontario

The recommendations in this statement do not indicate an exclusive course of treatment or procedure to be followed. Variations, taking into account individual circumstances, may be appropriate. 